\title{
Varför vi älskar att hata Sverigedemokraterna
}

\section{Anders Hellström}

SAMMANDRAG: Anders Hellström undersöker i sin artikel Sverigedemokraternas (SD) roll i svensk politik. Huvudargumentet är att vi älskar att hata SD och att vi genom vårt gemensamma avståndstagande uttrycker gemenskap och samhörighet. Enligt denna logik har SD inte bara fel åsikter; de representerar också onda typer. Hellström menar att vi för att förstå SD:s utanförskapsposition i svensk politik måste beakta politisk kommunikation som någonting utöver rationella intressen eller skapande av kompromisser. Politik handlar också om förlösande av känslor, om att formulera visioner och agera ut sina passioner för eller mot ett specifikt politiskt projekt. Studien utgår ifrån SD:s politiska riktlinjer inför valet 2010 och den offentliga debatten om partiet, uttryckt i den löpande medierapporteringen. Teoretiskt anknyter Hellström till den akademiska diskussionen om vilka begrepp, exempelvis "nationalism" och "populism", som används för att klassificera den typ av parti som SD utgör. Texten kryddas av löpande referenser till den dagsaktuella politiska debatten.

NYCKELORD: Sverigedemokraterna; svenskhet; Sverige; nationalism; populism; politik; offentlig debatt.

PUBLICERINGSHISTORIK: Originalpublicering.

ANDERS HELLSTRÖM är doktor i statsvetenskap och verksam som forskare vid Malmö Institute for Studies of Migration, Diversity and Welfare (MIM) och lektor vid institutionen Globala politiska studier (GPS) vid Malmö högskola.

FÖRSLAG PÅ KÄLLANGIVELSE:

Hellström, Anders (20I3) "Varför vi älskar att hata Sverigedemokraterna", i Det vita fältet II. Samtida forskning om högerextremism, specialnummer av Arkiv. Tidskrift för sambällsanalys, $\mathrm{nr}$ 2, s. 69-99.

DOI: http://dx.doi.org/IO.I3068/2000-6217.2.3

(C) Anders Hellström/Arkiv förlag \& tidskrift 2013 (publicerad ı6 september 20I3)

Artikeln distribueras enligt en upphovsrättslicens från Creative Commons:

Erkännande-Ickekommersiell-IngaBearbetningar 3.0 Unported, som medger fri ickekommersiell användning och spridning i oförändrat skick så länge källan anges. 
Arkiv. Tidskrift för samhällsanalys är en sakkunniggranskad vetenskaplig tidskrift för samhällsvetenskap och historia. Samtliga artiklar publiceras fritt tillgängliga på:

$$
\text { www.tidskriftenarkiv.se }
$$

(beständig länk, DoI: http://dx.doi.org/IO.I3068/2000-62I7)

Den här artikeln finns tillgänglig i följande format:

PDF \& HTML: via beständig länk, DOI: http://dx.doi.org/IO.I3068/2000-62I7.2.3 EPUB: ingår i e-boksutgåva av numret, ISBN: 978 9I 7924254 I TRYCK: ingår i bokutgåva av numret, ISBN: 978 9I 79242558

Grafisk utformning och sidnumrering är identisk i pdf och tryck.

Samtliga artiklar i nr 2 (2013), Det vita fältet II. Samtida forskning om högerextremism, nås via beständig länk, DoI: http://dx.doi.org/I0.13068/2000-6217.2 redaktion för numret: Mats Deland, Paul Fuehrer och Fredrik Hertzberg

Arkiv. Tidskrift för sambällsanalys ISSN: 2000-62I7 (för elektronisk resurs) ISSN: 2000-6225 (för tryckta nummer)

ges ut av

Stiftelsen Arkiv för främjande och spridning av samhällsvetenskaplig och historisk forskning

genom

Arkiv förlag \& tidskrift

Box 1559 SE-22I OI Lund BESÖK: L Gråbrödersg 3 c, ipg TEL: O46-I3 3920

ARKIV FÖRLAG: arkiv@arkiv.nu·www.arkiv.nu TIDSKRIFTEN ARKIV: red@tidskriftenarkiv.se.www.tidskriftenarkiv.se

ANSVARIg UTGIVARE \& CHEFREDAKTÖR: Sven Hort AdMinistrativ Redaktör: David Lindberg ReDAKTörer: Paavo Bergman, Lisa Kings, Zhanna Kravchenko 


\section{Varför vi älskar att hata Sverigedemokraterna}

ANDERS HELLSTRÖM

Nobelstiftelsen har som regel att bjuda in partiledarna för samtliga riksdagspartier till den årliga Nobelmiddagen. Prisceremonin frekventeras av kungafamiljen, pristagarna och andra berömdheter. Sveriges Television (SVT) sänder direkt och tittarna får lektioner i alltifrån klädkreationer, middagens komposition, litteraturpristagarens omvärldsanalys och de senaste rönen i fysik, kemi, medicin och ekonomi. År 2007 valde Nobelstiftelsen att låta den kommersiella tv-kanalen $\mathrm{TV}_{4}$ överta sändningsrättigheterna. $\mathrm{TV}_{4}$ lät sändningarna, som pågick med inslag från morgon till sen kväll och följdes av fler än I,3 miljoner tittare, vara reklamfria på grund av Nobelceremonins starka varumärke (TT Spektra 2007). ${ }^{\mathrm{I}}$

Nobelmiddagen har blivit en nationell högtidsdag, dels för att entusiasmera det folkliga intresset för vetenskapliga rön, dels för att sätta Sverige på kartan. I den svenska riksdagen finns det ett parti som tydligare än andra företräder Sverige som en ödesbestämd gemenskap. Partiet är Sverigedemokraterna (SD) och dess partiledare, Jimmie Åkesson, är besviken över att inte ha blivit inbjuden till festligheterna. Han beklagar att Nobelstiftelsen har uttryckt ett politiskt ställningstagande mot

I. Året efter återfår SVT sändningsrättigheterna.

Jag vill tacka Fredrik Hertzberg, övriga redaktörer och en anonym sakkunniggranskare för värdefull återkoppling. 
honom som person och mot hans parti, men känner samtidigt: "världen går inte under för att jag inte får gå på Nobelfesten, man har viktigare saker att göra som politiker" (Ström 20Io).

Michael Sohlman är vd för Nobelstiftelsen och motiverar sitt och en enig styrelses beslut med att Nobelstiftelsen är en privat stiftelse och att de själva väljer vilka de vill bjuda. Dessutom, menar Sohlman, går SD:s värderingar på tvärs med Alfred Nobels uttryckliga och på sin tid kontroversiella önskan om att inte låta nationstillhörighet avgöra vem som ska tilldelas priset. På detta svarar Åkesson: ”Jag har läst Alfred Nobels testamente och det står inget om hur många invandrare man ska vilja ta emot för att gå på Nobelfesten” (Ström 20IO).

Jag föreslår att vi kan se Nobelmiddagen som ett ritualiserat evenemang med syftet att uppmärksamma internationella forskningsrön på nationell mark, och där den svenska kungafamiljens närvaro, dagspressens myckna uppmärksammande av middagen och etermediernas satsning på evenemanget förstärker det nationellas närvaro. Etnologen Barbro Blehr (2000), som studerat nationaldagsfirande i Norge, framhäver betydelsen av samhälleliga ritualer för nationell sammanhållning eftersom dessa berör och engagerar många människor i ett gemensamt (nationellt) projekt. Middagen är, för att parafrasera nationalismforskaren Michael Billig (1995), ett sätt att "flagga för nationen" och den tjänar som en påminnelse om medborgarnas lojalitet och tillhörighet till Sverige.

Nobelmiddagen är inte vilken middag som helst och valet av gäster skiljer sig förstås från en vanlig middagsbjudning i vänkretsen. Evenemanget äger en särskild tyngd i det nationella medvetandet. I det avseendet är valet att utesluta Jimmie Åkesson från festligheterna förvisso inte självklart ett politiskt beslut, men att exkludera Åkesson från listan över inbjudna gäster äger ändock en symbolisk betydelse: SD hör egentligen inte hemma i offentlighetens finrum.

Varför betraktas inte SD som vilket parti som helst? Det borde vara möjligt att "diskutera legitimiteten och effekterna av det mångkulturella samhället", påpekar den norske statsvetaren Anders Ravik Jupskås i en debattartikel i Sydsvenskan, på samma sätt som partier på vänsterkanten bereds möjlighet att ifrågasätta kapitalismen (Ravik Jupskås 20Io). Bland annat mot bakgrund av detta anser jag att vi bör fråga oss vilken roll SD 
fyller i svensk politik. I den här artikeln argumenterar jag för att partiets närvaro i offentligheten påminner oss om att politik inte bara handlar om att administrera redan fattade beslut utan också om att kommunicera en bild av vad som kännetecknar det goda samhället, och att politik utgår från känslor.

Att Åkesson utesluts från Nobelmiddagen trots sin nyvunna riksdagsplats ger vid handen en utanförskapsposition i den nationella politiska miljön. Partiet utnyttjar flitigt denna roll, vilket mitt nästa exempel är tänkt att illustrera. Under riksdagens öppnande den 5 oktober 2010 höll biskop Eva Brunne traditionsenligt en gudstjänst i Storkyrkan för de förtroendevalda. Samtliga SD:s nyvalda riksdagsledamöter var närvarande, vilket är rimligt med tanke på att partiet värnar ceremonier där nationell samhörighet "flaggas för". Jimmie Åkesson hade dagen till ära valt att ikläda sig en folkdräkt från Blekinge, sitt hemlän. I sin predikan valde Eva Brunne att tala om människors lika värde och hon hänvisade till de antirasistiska demonstrationer som hållits dagarna före. Hon vände sig mot

den rasism som säger att du är inte lika mycket värd som jag. Du ska inte ha samma rättigheter som jag. Du är inte värd ett liv i frihet. Och detta av en enda grund - att vi råkar vara födda i olika delar av vår värld. Det är inte värdigt en demokrati som vår att göra skillnad på människor (Brunne 20IO).

Medan biskopen uttalar dessa ord reser Åkesson sig upp, ser sig omkring och paraderar ut från Storkyrkan med flickvännen vid sin sida och med partikamraterna efter sig. Efter predikan fick biskopen varma, kvardröjande applåder av de församlade riksdagsledamöterna.

Dagen efter liknar kolumnisten Kerstin Weigl SD:s beteende vid ouppfostrade tonåringar som slänger igen dörren efter sig om de inte får precis som de vill (Weigl 20Io). Aftonbladets politiska redaktör, Lena Melin, påpekar att Brunnes predikan ligger i linje med det evangeliska budskapet om att inte göra skillnad på människor. Hon anmärker att SD:s agerande var obegåvat och att det befäster bilden av partiet som omoget och opålitligt (Melin 20IO). Flera reagerar med bestörtning på det inträffade. Moderaternas gruppledare i riksdagen, Anna Kinberg Batra, menar att uppträdandet var exceptionellt och att det tydligt visar 
att SD är ett extremparti eftersom man blir så upprörd över en predikan som pläderar för medmänsklighet (Henriksson 20Io). Åkesson invänder att biskopen tog ställning för de vänsterextremister som under lång tid misshandlat och trakasserat SD-anhängare (Stenberg 20Io). Den tolkning av uttåget som dock vunnit mest gehör fäster vikt vid att SD väljer att genomföra detta etikettbrott just medan biskopen talar om människovärdets okränkbarhet och att detta i sin tur antyder att Sverigedemokraterna i grunden är ett extremt parti med extrema, låt oss säga osvenska, värderingar.

Demonstrationerna, som biskopen hänvisade till i sin predikan, gav uttryck för majoritetssamhällets kollektiva avståndstagande mot såväl rasism som mot SD. De "goda krafterna" mobiliseras mot främlingsfientliga strömningar som förmodas ha utnyttjats av SD för att vinna röster. Därigenom manifesteras också en särpräglad uppfattning om en nationell självbild, nämligen att svenskarna trots SD:s intåg i riksdagen är fullgoda demokrater som välkomnar dem som knackar på fosterlandets port. I denna gemenskap har inte $\mathrm{SD}$, som i riksdagsvalet 2010 erövrade 20 mandat, en självklar plats. ${ }^{2}$

Nobelmiddagen och riksdagens öppnande betecknar två samhälleliga riter varigenom den nationella samhörigheten manifesteras. I dessa sammanhang är SD avskilda från majoritetssamhällets föreställningar om den "goda nationen". Exkluderingen från Nobelmiddagen och uttåget från Storkyrkan är två olika exempel på att SD varken av andra ses eller alltid ser sig själva som vilket parti som helst. I det ena fallet väljer en extern aktör, Nobelstiftelsen, att utesluta SD från gästlistan till årets kanske mest högtidliga och medialt uppmärksammade middag. I det andra fallet utför SD själva, med Åkesson i spetsen, en symbolisk aktion som uttrycker utanförskap.

2. "Svensk flyktingopinion fortsätter att bli allt mer generös", konstaterar Marie Demker (2012, s. 95), professor i statsvetenskap, i en undersökning av svenskarnas inställning till invandring och det mångkulturella samhället. År 1992 svarade hela 65 procent av svenskarna att det vara ett ganska bra eller mycket bra förslag att ta emot färre flyktingar; 2OII var den siffran nere i 4I procent. Oavsett synpunkter på att det fortfarande är väldigt många som anser att det finns för många invandrare i Sverige (jfr Ekman \& Poohl 2oro, s. 384) är trenden att inställningen till flyktingmottagandet går i positiv riktning. Det går således inte att förklara SD:s frammarsch med att Sverige blivit mer främlingsfientligt. 


\section{Varför vi älskar att hata}

Få står oberörda inför SD:s framfart och många har åsikter om vad partiet representerar, liksom vad som kan förklara varför partiet nu har tagit klivet in i riksdagen. Oftast sker detta utan referenser till övriga Europa. I ett komparativt perspektiv är SD fortfarande ett litet parti med begränsat inflytande, jämfört med exempelvis Dansk Folkeparti i Danmark. En minoritet av svenskarna gillar att Sverige har fått ett nytt riksdagsparti. Andra har en mer njugg inställning, men uppskattar samtidigt att någon vågar kritisera den så kallade massinvandringen. Den stora majoriteten svenskar är fundamentalt misstänksamma, för att inte säga hatiska, gentemot SD (jfr Holmberg 2007).

För att förstå SD:s utanförskapsposition i svensk politik är det, tror jag, väsentligt att beakta politisk kommunikation som någonting utöver aggregering av rationella intressen eller skapande av kompromisser genom förnuftsbaserad deliberation; politik handlar också om känslor, om att formulera visioner och agera ut sina passioner för eller mot ett specifikt politiskt projekt (se t.ex. Mouffe 2008). Kärleken till hatet av SD handlar om identifikation, vilket kommer till uttryck i att många människor och organisationer av olika politiska kulörer deltar i mobiliseringen mot en utpekad gemensam moralisk fiende - som att vi applåderar Eva Brunnes predikan eller instämmer i Nobelstiftelsens val att utesluta Åkesson från Nobelmiddagen. Vi älskar att hata SD därför att detta avståndstagande uttrycker gemenskap och en känsla av att delta i ett gemensamt politiskt projekt. Vi älskar att hata SD därför att partiet står som exponent för "vad vi inte är”, vilket uttrycks i föreställningar om SD-väljare som sprungna ur "de outbildade massorna" som låter sig förföras av främlingsfientlig demagogi eller att partiet som sådant, olikt andra parlamentariska partier, graderar människor på ett sätt som är oförenligt med demokratiska värderingar.

I liknande ordalag beskriver Slavoj Žižek (2000) hur "vi" (de "goda demokraterna") älskade att hata den nu framlidne populistledaren Jörg Haider, vars parti FPÖ erövrade 27 procent av rösterna i det österrikiska parlamentsvalet 1999, för att "vi" därigenom kunde bekräfta "vår godhet". Det moraliska anslaget och den uppretade tonen också i den svenska debatten säger någonting om vilka "vi är" och hur "vi" bekräftar vår 
tillhörighet till den svenska nationella gemenskapen. Žižek hämtar inspiration från psykoanalysen för att förklara varför "de goda demokraterna" utser de så kallade högerpopulisterna till en politisk fiende, som "vi" kan demonstrera vår demokratiska samsyn mot (Žižek 2000, s. 5).

Ernesto Laclau återvänder i sin bok (2005) om den populistiska logiken just till Sigmund Freud. Den senare knöt samman den grundläggande livsdriften ("libido") med de emotionella band som sammanför människor i en kollektiv gemenskap. Tillhörigheten till gruppen omvandlas i denna identifikationsprocess, enligt Freud, till ett gemensamt egoideal och blir ett objekt för våra narcissistiska lustar (Laclau 2005, s. 54 ff.). Politikens passioner handlar i det avseendet om de sociala identifikationsprocesser som genererar tillhörighet genom att avstånd markeras mot det eller dem som anses hota vår sammanhållning. I ett psykoanalytiskt språkbruk inspirerat av dem franske psykoanalytikern Jacques Lacan kan man säga att "vi" kompenserar för vår fundamentala brist på "njutning" ("jouissance") genom att vi anklagar något eller någon som har stulit denna från oss (Mouffe 2008, s. 34). Identifikation är enligt detta resonemang immanent i och en förutsättning för människans varande i samhället.

Från denna utgångspunkt ifrågasätter Chantal Mouffe den rådande samförståndskulturen och den politiska koncentrationen kring partipolitikens mittcirkel i europeisk politik, vilket enligt henne öppnar för nya rörelser att mobilisera anhängare för alternativ som utmanar status quo. Genom att ta fasta på hur "vi älskar att hata SD" vill jag med denna artikel illustrera hur politikens passioner avspeglas i SD-antagonisternas - såväl de till vänster som de till höger - gemensamma avståndstagande mot en politisk utmanare som inte bara anses ha fel åsikter, utan också representerar "onda typer" och därmed utgör en reell politisk fiende (jfr Wodak 2002).

\section{Upplägg}

I artikeln resonerar jag - efter att ha givit en bakgrund till partiets uppkomst och utveckling - kring några av de epitet som använts om SD, såsom "extrem", "radikal", "höger" och "populism". Det är relevant för att skapa en förståelse av SD:s anspråk på att vara ett normalt parti för vanliga svenskar, samtidigt som kritikerna tenderar att stämpla partiet som 
extremt eller främlingsfientligt. Genom att granska begreppet "populism" lite närmare vill jag bringa ökad klarhet i politikens känslomässiga drivkrafter och den representativa politikens latenta dynamik.

I kölvattnet av SD:s inträde i riksdagen sker en omförhandling av nationella identiteter. Jag argumenterar för att vi kan förstå debatten om SD i svensk press som ett uttryck för olika sätt att framhäva Sverige som en särskilt moraliskt god nation, en kamp mellan nationalism och nationalism. Materialet jag utgår ifrån är SD:s politiska riktlinjer inför valet 20 Io och den offentliga debatten om partiet, uttryckt i den löpande medierapporteringen.

De möjliga svaren på frågan om varför vi älskar att hata SD är också en bekräftelse på de goda demokraternas "sunda nationalism”. Det vill jag åskådliggöra och problematisera.

\section{Quo vadis Sverigedemokraterna?}

På väg till sminklogen på valnatten möter Vänsterpartiets ledare Lars Ohly SVT:s reporter Kristian Luuk som på sitt sedvanliga, humoristiska vis meddelar att Jimmie Åkesson redan sitter där. Ohly vänder på klacken. Han vägrar dela loge med SD:s partiledare och förklarar senare för SVT: "Jag representerar alla de som Sverigedemokraterna är emot och jag tänker aldrig befatta mig med rasister" (Lewander 20Io). Ohlys aktion må vara stark och påfallande direkt, men den är inte ovanlig. En vanligt förekommande tankefigur i debatten om SD har varit att partiet är en "ulv i fårakläder". Även om partiet successivt har försökt skapa en demokratisk yta är SD enligt denna argumentation fortfarande i grunden odemokratiska, rasistiska och potentiellt våldsamma. Den före detta partiledaren för Kristdemokraterna, Alf Svensson, skriver utifrån denna position i Göteborgs-Tidningen:

Sverigedemokraterna måste ställas fram, avklädda och avslöjade, och det är deras nationalegoism och deras odemokratiska människosyn som ska framstå i all sin ynkedom. Vår tids största moraliska skam och utmaning är självfallet att det snackas och proklameras så mycket om ett universellt människovärde, alltmedan dolska resonemang om "dom och vi-samhället" smyger sig på oss (Svensson 2007). 
Det moraliska anslaget är explicit: SD har inte bara fel politik, de representerar också "onda typer" och det är vårt ansvar att genomskåda deras egentliga budskap. Många politiker, experter och journalister har använt sig av ett liknande språkbruk. De som går längst är inte blyga för att koppla SD:s föreställningsvärld till I930-talets nazism. Thage G. Peterson, tidigare socialdemokratiskt statsråd och talman i riksdagen, hävdar i Sydsvenskan:

Ingen som vill bekämpa Sverigedemokraterna och andra nazistinfluerade rörelser kan bortse från nazismens historia. Hur fanatiska och sjuka åsikter då var upphov till krig, misär och förintelse. Sverigedemokraternas åsikter idag om antisemitism och främlingsfientlighet hör nära ihop med nazismens ondska och förbrytelser (Peterson 2007).

Det kan verka underligt att etablerade politiska profiler som Thage G. Peterson och Alf Svensson uttalar sig så kraftigt om ett parti, som enligt den egna självbilden har gjort upp med det förflutna för att numera företräda "de vanliga svenskarna”. SD finner sin näring i det normala, snarare än i det extrema. Så har det inte alltid varit.

\section{Bakgrunden}

Den 30 november 199I organiserar SD en demonstration för att hylla Karl XII (I682-I7I8). Ungefär I ooo personer deltar i manifestationen, som slutar med kaos och våld. Författaren och journalisten Gellert Tamas (2002, s. 194) har beskrivit stämningen så här:

Hundratals högerarmar lyftes mot skyn medan ropen taktfast ekade. Sverigedemokraternas ledare startade en egen talkör: "UT MED PACKET! UT MED PACKET!" vrålade Anders Klarström i sin megafon och snart genljöd ropen från deltagarna i tåget. Hundratals röster bar partiledarens hat vidare. Längst fram i tåget, bland de blågula flaggorna, vajade en vit flagga med en svart swastika i mitten.

På partiets första årsmöte 1989 valdes Anders Klarström, med ett förflutet i det nazistiska Nordiska rikspartiet, till talesman för partiet (Larsson \& Ekman 200I, s. I26). Några medlemmar av partistyrelsen hade varit medlemmar i Bevara Sverige svenskt (BSS) eller Vitt ariskt motstånd (VAM), medan andra varit inriktade på att producera vitmaktmusik som 
var populär också utanför de högerextrema kretsarna i början på I990talet. För den som söker bevis för partiets rasistiska förflutna finns det gott om stoff från partiets tidiga historia. Enligt Ekmans och Poohls (20IO, s. I45-155) uträkningar hade drygt 60 procent av ledamöterna i partistyrelsen på olika sätt kopplingar till nazianstrukna organisationer under åren 1989-1995. 39,5 procent av partiets kandidater i valet 1994 hade före, under eller ibland också efter sin kandidatur varit involverade i den svenska nazistiska rörelsen.

Efter hand har SD genomgått flera förvandlingar. Personer har bytts eller sparkats ut, och framtoningen har successivt blivit mer salongsfähig. Under hösten 2012 införde partiet en nolltolerans mot rasism i de egna leden (Orrenius 2012). Det dröjde dock innan partiet fick framgångar i valurnorna, vilket delvis kan förklaras med $\mathrm{Ny}$ demokratis $(\mathrm{NyD})$ entré i riksdagen år 1991. $\mathrm{NyD}$ nådde då 6,7 procent i riksdagsvalet, med en retorik som riktades mot etablissemang, skatter, byråkrati och efter hand alltmer mot invandring och invandrare. $\mathrm{NyD}$ försvann redan nästföljande val, I994, men SD lyckades ändå inte attrahera mer än I4 000 röster det året.

Inför riksdagsvalet 1998 fick partiet visst finansiellt stöd från Nationella fronten i Frankrike och det vann åtta fullmäktigemandat. Efter hand anslöt sig allt fler namnkunniga personer till partiet som exempelvis de nu bortgångna politiska profilerna Sten Andersson (tidigare Moderaterna och Socialdemokraterna) och Sven-Olle Olsson (tidigare Centerpartiet), känd som initiativtagare till folkomröstningen om flyktingmottagande i Sjöbo. I valet 2002 tog partiet sammanlagt 50 kommunala mandat, men det var inte förrän i valet 2006 som partiet nosade på riksdagsplatser med sammanlagt 2,93 procent av väljarkåren bakom sig och mandat i I44 kommuner.

Partiets utveckling är häpnadsväckande; det "består inte längre av skinnskallar, snarare av skalliga män", som det heter i en ledare i Expressen (Forsberg 2006). Enligt partiets egen kronologi var det framför allt under 200I som partiet på allvar gjorde upp med sitt förflutna. Detta ledde bland annat till att det mer extrema partiet Nationaldemokraterna bildades. Jimmie Åkesson, som valdes till partiordförande 2005, blev medlem i SD 1995 men talar ogärna om partiets historia innan dess. 
Många som väljer att hata SD gör det på grundval av partiets förflutna. Men vad kännetecknar SD som politiskt parti 20I3? Den frågan diskuteras härnäst.

\section{SD som populistiskt radikalhögerparti}

Cas Mudde (2007) inleder sin studie av vad han kallar de "populistiska radikalhögerpartierna” i Europa med att lista mer än 20 olika etiketter som använts för att klassificera den partifamilj som inkluderar bland annat Nationella fronten och Lega Nord. Hans slutsats är att forskningen varken har kommit överens om vad familjen ska heta eller hur dess gemensamma drag ska definieras. Mudde urskiljer tre attribut. Det första är nativism som utgår från att "de inhemska" har exklusiv företrädesrätt till "sin plats"; att Sverige tillhör svenskarna främst och så vidare (Mudde 2007, s. 22). Utifrånkommande personer och idéer (de icke-inhemska och det icke-inhemska, the nonnatives) utgör ett potentiellt hot mot den inhemska samhällsordningen som majoritetsbefolkningen byggt upp över tid. Oftast sammanfaller den kulturella gemenskapen med nationalstatens gränser. Den andra komponenten är auktoritarianism. Mudde definierar detta som en tilltro till ett strikt ordnat samhälle där brott mot den auktoritära ledningen ska straffas hårt (2007, s. 23). Detta drag är kopplat till en tilltro på den starka ledaren som i sin person förkroppsligar folkviljan. Den tredje beståndsdelen, slutligen, är populism, som utgår från den täta fusionen mellan folk och nation. Den populistiska ideologins förespråkare vill företräda en oförställd folkvilja och ett genuint sunt förnuft.

Utifrån Muddes definition av "nativism" är det tvivelsutan så att SD utgår från en nativistisk grundsyn. Det gamla slagordet "Bevara Sverige svenskt" används mindre frekvent nu för tiden, men grundsatsen är, som det heter i SD:s kulturpolitiska manifest: "Låt Sverige förbli Sverige" (Sverigedemokraterna 20ıoa). Utifrån kommande impulser, såväl personer som idéer, är inte principiellt exkluderade från den hävdvunna nationella gemenskapen men de måste i så fall försvenskas. Vad gäller "auktoritarianism" kan vi notera att SD föreslår att strafftröskeln ska höjas: "I vårt Sverige står det straff en brottsgärning medför i rimlig proportion till det begångna brottet och är i samklang med den folkliga rättsupp- 
fattningen” (2OIOa). SD åberopar mer auktoritära samhällsstrukturer, i bemärkelsen en mer strikt ordnad samhällsordning, som ett sätt att mildra den utbredda rotlöshet och vilsenhet som många svenskar känner i dag, detta enligt SD:s sätt att se. Hävdvunna strukturer försvaras gentemot diverse försök att luckra upp exempelvis könsskillnader, den heteronormativa kärnfamiljen, betydelsen av ordning och reda i skolan och kulturskillnader mellan "infödda svenskar" och "invandrare". Trygghet och välfärd ställs mot oro och mångkultur.

Antropologen Arjun Appadurai (2007) har identifierat två parallella rörelser som utgör konkurrerande krafter i en värdepolitisk konfrontation i Europa efter kalla krigets slut. Den ena sidan samlar de nya sociala rörelserna, vilka kan utgå från miljöfrågornas pregnans, nationsgränsers begränsade giltighet eller feminismens uppgörelse med särartstänkandet (se vidare Wennerhag 2008). Som en reaktion på dessa rörelser mobiliseras på andra sidan krafter som markerar behovet av tydliga nationsgränser i stället för mångkultur, protektionism i stället för fri handel och stabila könsidentiteter i stället för genuspedagogik. Dessa rivaliserande krafter rör sig i det globala och kretsar kring frågeställningar om civilisation, kultur och nation som inte enkelt passar in på höger-vänster-skalan. Vi kan förstå dessa värdepolitiska stridigheter, menar Appadurai (2007, s. 23), utifrån en utbredd "ängslan inför det ofullständiga".

Det finns ett uppdämt behov av att åter markera faktiska gränser mellan "vi" och "dem". SD bejakar traditioner och stabilitet för att befrämja samhällskroppens enighet. Men även aktörer i huvudfåran varnar för ökade samhällsklyftor, brist på ordning i skolan och att integrationspolitiken skulle vara ett fullständigt fiasko. ${ }^{3} \mathrm{SD}$ utgår från redan etablerade strömningar i samhället och radikaliserar dessa för att exempelvis föreslå inskränkningar i flyktingmottagandet.

Är SD ett populistiskt radikalhögerparti? Mudde definierar "radikal" som opposition mot fundamentala liberaldemokratiska värderingar medan "höger" förklaras som en tilltro till naturliga samhälleliga hierarkier (Mudde 2007, s. 26; Kiiskinen \& Saveljeff 20IO, s. 46 f.). Hans-Georg Betz och Carol Johnson (2004) påpekar att de populistiska radikalhögerpartierna utgör ett fundamentalt hot mot den liberala - läs: toleranta -

3. Jag diskuterar och ifrågasätter dessa antaganden i Hellström (20IO). 
förståelsen av demokrati. Visst anammar dessa partier en utpräglad opportunism, men dold av retoriken nalkas en extrem ideologi, menar de. De populistiska radikalhögerpartierna representerar därmed, enligt Betz och Johnson, en rörelse som strävar efter att ersätta liberaldemokratiska institutioner med en ny "etnokratisk regim" ${ }^{4}$. Det som gör det svårt att bemöta dessa partier, avslutar Betz och Johnson, är att de omfamnar både extremism och demokrati.

Analyser som de nyss nämnda medför en risk, menar Mudde, i det att man ensidigt utgår från partier i periferin i stället för att studera förskjutningar i "normaliteten", mittpunkten. Han föredrar därför termen "radikal" framför "extrem". Ett extremt parti har föga respekt för de representativa institutionerna, som exempelvis polis- och rättsväsende eller den partipolitiska arenan, medan ett radikalt parti agerar inom systemet. De populistiska radikalhögerpartierna söker politiskt inflytande företrädesvis genom parlamentariska kanaler och respekterar oftast de grundläggande demokratiska spelreglerna. Partierna hotar inte att upplösa det liberaldemokratiska systemet, men deras politik kan likväl gå på tvärs med etablerade uppfattningar om tolerans, mångkulturalism och likabehandling.

\section{SD som högerparti}

Epitetet "höger" är också svårhanterligt. SD ser sig självt som ett mittenparti och att döma av ett par genomförda studier av SD:s väljare efter valet 2006 finns det inte heller någon anledning att placera partiet tydligt till höger om det borgerliga blocket (se vidare t.ex. Sannerstedt 2008; Holmberg 2007). Mudde betonar att det sällan eller aldrig är ekonomiska frågor som står i förgrunden för dessa partier (Mudde 2007, s. II9). Han konstaterar att flera populistiska radikalhögerpartier inte heller anammar en nyliberal ekonomisk-politisk doktrin, utan att vissa - däribland SD snarare bör beskrivas som välfärdschauvinistiska (jfr Meret 2009, s. 209). SD ser sig själva som värdekonservativa (det vill säga till höger på den sociokulturella skalan), men som vänster vad gäller fördelningspolitik, det vill säga att man försvarar den skattefinansierade välfärden (Skalin 20IO).

4. Etnokrati är ett system enligt vilket den politiska makten innehas och utövas av ett privilegierat etniskt kollektiv. 
SD uppvisar en idémässig likhet med det tankegods som utvecklades av den franska högern efter Charles de Gaulles fall, den så kallade franska "nya högern" (nouvelle droite). I korthet innebär denna doktrin att kulturer (oftast utifrån nationalstaten som referensram) varken kan eller bör blandas eftersom kulturskillnader är att betrakta som oöverstigliga och ogenomträngliga. Denna ideologiska handlingslinje kan också beskrivas som "etnopluralistisk", det vill säga att olika kulturer eller etniska grupper inte nödvändigtvis är hierarkiskt ordnade, som i klassisk rasism, samtidigt som man betonar varje grupps naturliga och unika (nationella) karaktär. Enligt sociologen Jens Rydgren (20IO, s. 19) är etnopluralismen - av vissa också beskriven som en kulturrasism (Taguieff 1990) - det som främst förenar medlemmarna i den populistiska radikalhögerfamiljen.

Min slutsats är att begrepp som "extrem", "radikal" eller "höger" är behjälpliga för att finna gemensamma referenspunkter i en brokig skara partier inom europeisk politik som vill begränsa invandringen till det egna landet. Samtidigt riskerar samma begrepp fördunkla en djupare förståelse för den nationella kontext i vilken dessa partier opererar - i relation till vad är SD radikalt, extremt eller höger? Det är just relationen mellan exempelvis "det extrema" och "det normala" som är relevant att beakta för att förstå varför så många hatar SD. Jag föreslår därvidlag att begreppen "nationalism" och "populism", vilka behandlas i nästa avsnitt, hjälper oss att förstå denna relation.

\section{Sverigedemokraterna som nationens räddare och folkets vänner}

Enligt den egna självbilden är SD:s ideologi nationalistisk och numera också socialkonservativ. Nationalism som (smal) ideologi har vissa kärnvärden, vilka enligt Thomas Freeden (1998) utgår från ett uppvärderande av den egna nationen som en föreställd gruppgemenskap med vissa stabila karakteristika knutna till sig. Denna gemenskap är också anpassad efter en specifik uppfattning om ett territoriellt, lingvistiskt och kulturellt avgränsat rum (Freeden 1998, s. 75I-752).

SD:s politiska program handlar om att uppvärdera den egna nationen, vilket motiverar partiet till en rad ställningstaganden som är avsedda att motverka element utifrån, vilka förmodas äventyra samhällsgemenskapens enighet. De vill inrätta en särskild kulturell kanon med inspira- 
tion från Danmark, de vill lämna EU för att bejaka svenskarnas rätt att själva bestämma över sin vardag, de vill pressa tillbaka brottsligheten för att främja kulturell trygghet och tillit medborgarna emellan, de betonar att den svenska skolan ska bygga på en uttalat svensk värdegrund och de främjar en ekologisk utveckling genom att motverka import av "smutsig kolkraft från utlandet", för att ge några exempel (Sverigedemokraterna 20IOa).

Uppvärderandet av nationen är genomgående i SD:s politiska program, som det enstämmiga svaret på det svenska samhällets många utmaningar. Även de övriga riksdagspartierna gör i varierande utsträckning referenser till nationalism som utgångspunkt för samhällssolidaritet, för att uttrycka en positiv självrepresentation av det svenska samhället eller för att erbjuda visioner om hur ett nytt Sverige kan förverkligas. Men SD går längre och gör nationen och nationaliteten till en överordnande princip för politiskt reformarbete. SD utgör på det sättet ingen anomali i svensk politik och samhällsliv, men partiet utgår från och radikaliserar populariserade uppfattningar om vad som exempelvis kännetecknar "svensk kultur", som att folkhemmet är en gemensam berättelse som förenar svenskar i Sverige, eller att Astrid Lindgrens och Selma Lagerlöfs böcker är genuina skildringar av "det svenska". SD åberopar dessa referenser som delar av ett gemensamt symbolpaket för vad som håller ihop nationen (se vidare Hellström 20IO, s. IOI).

Det kan givetvis vara provocerande att partiet använder sig av dylika nationella ikoner för att föra fram sitt budskap. Men det är knappast förvånande att ett nationalistiskt parti väljer att knyta an till författare och politiska berättelser som också av andra förknippas med svenskhet. SD är inte heller ensamt om att manifestera behovet av en gemensam värdegrund. Drömmen om det förlorade paradiset, som folkhemsmetaforen förkroppsligar i partiets retorik, har en stark emotionell dragningskraft för presumtiva SD-väljare och även andra som är besvikna över vardagens förändrade livsvillkor. Ändå är det sannolikt många som älskar att hata SD just därför att de annekterar populära symboler för nationell tillhörighet. Debatten om SD är också en kamp om vem som har rätt att äga symbolerna för nationell gemenskap. SD ser sig själva som företrädare för "mannen på gatan"- deras symbolspråk för svenskhet och nationell 
enighet må provocera en smalare "kulturelit", enligt deras sätt att se, men det är samtidigt ett budskap som förutsätts appellera till denna "mannen på gatan”.

Inför årsmötet i Karlskrona i maj 2007 talar Jimmie Åkesson (Åkesson 2007) om sina och andra SD-representanters erfarenheter av att inte ha tillgång till samma information som övriga partier. Han hävdar att demokratiskt valda SD-representanter lider av att dagligen bli diskriminerade $\mathrm{i}$ sitt politiska arbete. Eftersom SD är "folkets vänner" är detta inte bara en skymf mot partiet, utan mot hela det svenska folket. Åkesson anknyter, som så ofta, till Sylvester Stallones rollkaraktär i Rockyfilmerna, Rocky Balboa, som ständigt reser sig trots alla slag han tvingas utstå. Han knyter ihop sitt tal med att precisera "SD-andan":

Partivänner, man hånar oss, bespottar oss, slår oss, kastar sten på oss, avskedar oss från våra jobb, kastar ut oss från våra fackföreningar. Och ändå står vi där, hela tiden lite större, lite starkare. Mod, civilkurage, heder, solidaritet, stolthet, sammanhållning och, inte minst, en fast övertygelse om att vi har rätt, att det är vi som är den goda sidan.

SD ser sig som demokratins förkämpar, vars politiska arbete försummas och motarbetas av "eliterna". Ingen vill vara populist, men alla vill vara en vän av folket. I den akademiska litteraturen finns det en uppsjö av företeelser, rörelser och partier som har försetts med denna etikett. Frågan är om dessa egentligen har någonting gemensamt utöver att de kallats för populistiska. Margaret Canovan (2004, s. 243) ger en målande beskrivning av detta förhållande:

Det finns ingen uttalad gemensam historia, ideologi, politik eller social bas. Beteckningen brukar användas utifrån, ofta i nedsättande syfte. [...] Det är svårt att föreställa sig att låt säga Tony Blair, Hugo Chávez och Jean-Marie Le Pen skulle vidkänna politiskt släktskap, än mindre att dessa tre skulle förenas i hyllning av sina föregångare i Rysslands narodniker och USA:s People’s Party.

Inte sällan är SD föremål för kritik om att utnyttja en populistisk retorik, att man ägnar sig åt billigt röstfiske och därför inte anses vara ett seriöst politiskt alternativ. SD är i sin tur tydliga med att företräda "verklighetens folk". Den nämnda retoriska figuren har tidigare använts på olika sätt 
av Ny demokrati och senare också av Kristdemokraterna för att urskilja de politikområden som engagerar "vanliga människor" i vardagen i stället för att fokusera på de frågor (som till exempel homoadoption eller månggifte) som enbart antas sysselsätta ett privilegierat fåtal, det vill säga "kultureliten".s

Populismforskaren Paul Taggart (2002) hävdar att förekomsten av populistiska rörelser och partier prövar den representativa politikens funktionsduglighet och legitimitet. Populism är både en nödvändig förutsättning för och ett potentiellt hot mot det demokratiska styrelseskicket. Den politiske teoretikern Philip Abbott (2007) poängterar att förekomsten av populism lika gärna kan vara ett hälsosymptom som ett sjukdomstillstånd. Enligt Abbott kan populismens känslomässiga drivkraft liknas vid två möjliga sätt att uttrycka ilska på:

Är populismens två ansikten - en xenofobisk, rasistisk och benägen att acceptera demagoger och utomkonstitutionella medel, den andra anständig, human, påhittig och kommunitär - också konsekvenserna av ilskans två ansikten, där den ena vill bygga upp och den andra vill bryta ned? (2007, s. 438)

Den populistiska ideologin kan således enligt den första betydelsen vara ett redskap för att vitalisera och berika den representativa politiken. Enligt den andra, som Abbott benämner "ilskans destruktiva kraft", utgör populism en främlingsfientlig, rasistisk kraft som lockar med förförisk demagogi. Abbotts två olika uttryck för populism kan liknas vid distinktionen mellan "radikal" och "extrem”. Den jämförelsen kan dels förtydliga populismens ambivalenta relation till den representativa demokratin, dels också SD:s balansgång i svensk politik mellan en rumsren demokratisk position och en extrem ytterlighetsposition utanför politikens finrum. Som svar på frågan varför vi älskar att hata SD är hänvis-

5. Göran Hägglund, partiledare för Kristdemokraterna, skriver på DN Debatt: "Sveriges radikala elit har kommit att bli den nya överheten. De som under flagg av att företräda minsta lilla påfunna rättviseanspråk har satt upp ett formidabelt minfält av ideologiska teorier, där konstruktioner, kategorier och förtryckarstrukturer ligger om vartannat. Den ena idén mer akademiskt tillskruvad än den andra och allt med udden ytterst riktad mot vanligt folks sätt att vara” (Hägglund 2009). Hägglunds ansats avfärdas i Aftonbladet (Osignerad ledare 20I0) som "billig populism". 
ningen till epitetet "populism" på sätt och vis förrädisk. Om vi avfärdar SD som ett populistiskt parti riskerar vi samtidigt att säga att politiken är förbehållet eliterna. Vi riskerar dessutom att avfärda politikens känslomässiga drivkraft. Låt oss titta närmare på detta.

Margaret Canovan (1999) ser populistisk mobilisering som en reaktion mot politics-as-usual. Populism är en viktig påminnelse, resonerar hon, om att politik inte bara handlar om att administrera fattade beslut utan också om att skapa och förverkliga förväntningar hos befolkningen. För att upprätthålla balansen och förtroendet mellan de styrande och de styrda fordras en balans mellan politikens "pragmatiska" sida (institutionella arrangemang för att hantera konflikter och motsättningar utan att någon blir skadad) och "förlösande" sida (föreställningar och förväntningar om det goda styret), påpekar Canovan. Hon gör en analogi till kyrkans roll i sekulariserade samhällen och utgår då från sociologen Max Webers idé om att kyrkan är en institution där religiös karisma är rutiniserad, där Guds röst medieras och tar sig institutionella uttryck. Avsaknaden av förlösande inslag i politiken, fortsätter Canovan, är som att leda en kyrka utan att församlingsmedlemmarna har en tro. I politik, liksom i religion, leder avsaknaden av tro till korruption och likgiltighet (I999, s. I6). Canovan hävdar att populism fyller en förlösande funktion som en direkt förmedlare av folkets röst i den representativa ordningen.

Populism uttrycker, enligt samhällsforskaren Yannis Stavrakakis (2004, s. 264), politikens affektiva dimension och är därmed varken fel eller rätt, god eller ond, utan en påminnelse om att en ensidig pragmatisk, eller teknokratisk, förståelse av politik kan leda till motstånd från krafter som utnyttjar parlamentariska kanaler för att få igenom ett ökat direkt folkligt inflytande. Som jag ser det: om politik inte bara handlar om att formulera intressen utan också om att mobilisera passion och entusiasm i folkets namn för den föreslagna politiken har populism en central plats i den representativa demokratin. Att vi älskar att hata SD är ett uttryck för politikens "förlösande" impulser och populistiska dragning till det känslomässiga i politiken.

SD vill framstå som radikala förnyare av den representativa ordningen genom att åberopa den populistiska distinktionen mellan folk och elit. SD markerar också behovet av en särskild moralisk gemenskap som garant för 
ett solidariskt samhälle, vilket enligt dem förutsätter kulturell likformighet. I den sverigedemokratiska retoriken ställs välfärd mot mångkultur och den skötsamma arbetaren ställs mot den kriminella invandraren. SD accentuerar etablerade föreställningar om svenskhet och om vad det innebär att vara svensk för att mobilisera väljare. SD hymlar inte med att de företräder en nationalistisk grundsyn. Debatten om partiet avslöjar dock att dess kritiker i sin polemik mot partiet målar upp en annan bild av Sverige att vara stolt över - nationalism står således mot nationalism.

\section{Nationalism mot nationalism}

SD:s inträde i offentligheten utmanar hävdvunna föreställningar om den nationella självbilden, om Sverige som ett land som är mer tolerant och bättre rustat att möta migrationens konsekvenser än andra länder. Mikael Ekman och Daniel Poohl (20I0) resonerar kring varför svenskar har svårt för att diskutera förekomsten av intoleranta attityder i Sverige:

Att tala om den svenska folkliga intoleransen är ett känsligt kapitel. Den platsar inte i den offentliga bilden av det öppna och toleranta Sverige. Föreställningen om Sverige som ett öppet och tolerant land är djupt förankrad i det svenska samhället, och därmed en del av vår självbild (20IO, s. 387).

SD utmanar föreställningar om Sverige som en särskilt öppen och generös gemenskap. SD utgår från att Sverige tillhör svenskarna främst. Det svenska medborgarskapet ska vara ett privilegium för svenskar som sätter sin lojalitet till Sverige före exempelvis religion, etnisk tillhörighet eller någon annan identitetsmarkör. De slår vakt om "det svenska" i syfte att stärka nationell samhörighet och stävja social oro och förespråkar en öppen svenskhet som innebär att även personer med ett ickegermanskt ursprung kan räknas som svenskar, förutsatt att viljan finns att "bli svensk". Likväl, Åkesson får inte gå på Nobelmiddagen och i andra sammanhang har företrädare för partiet blivit avskedade från sina jobb eller blivit utsatta för trakasserier och misshandel (se vidare t.ex. Orrenius 20I0; Jomshof 2008).

Reaktionerna på SD och deras politik tydliggör normer och värden som förenar svenskar i Sverige. Låt mig förtydliga. Enligt Freeden (1998) 
handlar nationalism om att känna stolthet och trygghet i att tillhöra en nationell gemenskap. Medborgarna i en nationalstat kan känna stolthet i att välkomna nya invånare med en öppen famn, att vi som folk skulle vara särskilt toleranta och gästvänliga (jfr Blehr 2000, s. 62). SD föreslår å sin sida: "[e] tt kraftigt utökat stöd till FN:s flyktingorgan, UNHCR, och de miljontals verkligt nödlidande flyktingar i världen som saknar möjligheter och resurser att ta sig ifrån konfliktområdenas närhet" (Sverigedemokraterna 2OIOb). SD motsätter sig inte att avsätta en mindre del av den nationella budgeten för att hjälpa de "verkligt utsatta" samtidigt som man kraftigt vill begränsa asyl- och anhöriginvandringens omfattning (20Iob). Precis som att en värdfamilj har rätt och möjlighet att skicka hem de gäster som bryter mot vad som gäller i det egna hemmet, ska den svenska invandringspolitiken anpassas efter principen att den svenska välfärden och landets välbefinnande sätts främst (Sverigedemokraterna 20Iob). "Gästerna” ska anpassa sig efter hur vi gör här och inte tvärtom. Jimmie Åkesson talar på SD:s valkonferens den 27 mars 20Io: "Sanningen är den, att jag har aldrig bett om att få integreras, jag har aldrig blivit tillfrågad om huruvida jag vill integreras och, partivänner, jag vägrar att integreras i detta kalla, splittrade, rotlösa samhälle som nu växer fram. Jag vägrar” (Åkesson 20Io). Det råder ingen tvekan, enligt SD:s sätt att se, att det är skillnad på att tillhöra värdfolket ("de kulturellt lika svenskarna") och att tillhöra gästpopulationen. Budskapet är oförblommerat nationalistiskt.

Ytterst få kulturpersonligheter attraheras av SD, men flera röster i den offentliga debatten förklarar - liksom partiets företrädare själva - SD:s popularitet med hänvisning till brister i den förda integrationspolitiken. Ett exempel på detta är den debatt som pågick på Sydsvenskans kultursidor i oktober 2006. Debatten inleddes med ett inlägg som författaren Fredrik Ekelund lät publicera. I artikeln argumenterade han för att SD får sitt stöd av vanliga strävsamma arbetare som "'fått nock' [...] av integrationens baksida”, som han uttryckte det. Han ägnade en stor del av artikeln åt att rada upp exempel på kriminalitet kopplat till invandrartäta områden. I en uppmärksammad passage gav han sig i kast med den omvända rasismen, som han menar drabbar etniska svenskar. Han påstod: "Den arbetarrörelse som byggde Landskrona och Malmö hölls 
samman ideologiskt av en gemensam skötsamhetskultur, är det då fel att kräva av de nya svenskarna just detta?" Ekelund hoppades att valresultatet, som han såg som ett resultat av att högerextrema krafter gynnats av kulturrelativism, kunde bli startskottet för en diskussion om vilken värdegrund som det svenska samhället bör vila på (Ekelund 2006). I det senare fick han åtminstone delvis rätt. Ekelund fick kritik för att basunera ut en romantisk klagosång över en stad som en gång hade jobb åt alla och att ställa "skötsamma svenska arbetare" mot "kriminella invandrare" (se t.ex. Awayez 2006), men debatten aktualiserade också den fråga som Ekelund efterlyste: Vad är det som kan och bör känneteckna den svenska kulturen - den värdegrund som ska förena svenskarna i Sverige? I detta avseende har SD:s närvaro i den offentliga debatten givit vidare resonans i de diskussioner som förts kring den svenska nationella identiteten. SD har, som det verkar, påverkat det svenska debattklimatet utan att själva ha varit aktiva i alla diskussioner. Även om det är ytterst få personer som uttryckligen står upp för SD och deras politik har allt fler journalister, författare, politiker och andra känt sig manade att profilera sig inom det fält som också är SD:s kärnområde: "svensken”, den hotade svenska nationen och ansatser till att vilja romantisera en svunnen era (se vidare Hellström 20IO).

\section{Sund nationalism}

Gränsen för vad som är acceptabel nationalism och vad som inte är det förskjuts och förändras hela tiden. SD utmärker sig genom att acceptera fler samhälleliga fenomen och händelser i nationalismens namn än de traditionella partierna gör. Det handlar ytterst om vilka positioner som är legitima i den offentliga debatten. Blehr (2000, s. 6I f.) påpekar att slagord som "Norge for nordmenn" kan brännmärka användaren och uppfattas som "ond nationalism" om det används av företrädare för mindre rumsrena partier och rörelser. Samma slogan, påpekar Blehr, kan dock rättfärdiga en rad politiska åtgärder som de flesta uppfattar som legitima och tolkar som utslag av "god nationalism". Vi reagerar antagligen annorlunda på om deltagarna i ett demonstrationståg med Nationaldemokraterna viftar med svenska flaggor och sjunger nationalsången eller om Jimmie Åkesson ikläder sig folkdräkt för att högtidliggöra riksdagens 
öppnande, jämfört med när en grupp grundskolelever gör samma sak under nationaldagsfirandet på Skansen. Nationalistiska uttryck uppfattas olika beroende på avsändare och sammanhang.

Möjligen är det så att nationalistiska rörelser och nationalistiska ideologier associeras med extremistgrupper som vill upprätta en ny stat, alternativt att bryta sig fria från en existerande stat. Alternativt kopplas nationalismen till 1900-talets brutaliteter och blodspillan. Nationalism är någonting som sker i periferin, där och då, men aldrig här och nu. Dessa synsätt, menar nationalismforskaren Michael Billig (1995, s. 6), undviker det sunda förnuftets nationalism - att nationalism oftast uttrycks mycket banalt, inte behöver vara våldsam och snarare kan bekräfta en hävdvunnen normalitet än vara någonting, per definition, avlägset eller farligt.

Om vi begränsar oss, fortsätter Billig, till att definiera nationalism som någonting som "de andra" sysslar med finns risken att vi undviker att se hur samtida utryck för nationalism inte framstår som nationalistiska, utan som naturliga inslag i vardagen. Billig lanserar begreppet "banal nationalism" som ett sätt att förstå hur nationalismen, även i dag och här, reproducerar nationen som en föreställd gemenskap genom dagliga rutiner som vi sällan är medvetna om. Man behöver inte resa långt för att bli påmind om att IKEA är ett svenskt företag, att Volvo är en svensk bil eller att Abba är en svensk musikgrupp. Utöver vardagliga företeelser bekräftas medborgarnas förväntningar om att tillhöra nationen genom samhälleliga ritualer (Blehr 200o, s. 9). Firandet av sjuttonde maj uppfattas, både av norrmännen och av andra, som ett glatt och ofarligt hyllande av den egna nationen. Detsamma kan antas gälla för Nobelmiddagen. Billig framhåller dock att de banala, implicita uttrycken för nationalism kan göra att de skarpare och mer kategoriska nationalistiska uttrycken blir mer plausibla. Acceptansen förskjuts. Som exempel finns det flera SD-kritiker som instämmer i påståendet att allt fler människor i det svenska samhället lider av utanförskap och att detta hänger samman med en fallerad integrationspolitik. SD kan, i sin tur, utnyttja en sådan föreställningsram för att rättfärdiga en restriktiv invandringspolitik och mer explicit hävda sambandet mellan en ökad invandring och ett ökat utanförskap, som nu senast i samband med Husbykravallerna. 
I den akademiska litteraturen används ibland termen "neo-nationalism" för att beskriva den typen av rörelser och partier som, likt SD, bejakar nationalstaten som en solid organism i en tid av upplevd social uppluckring. Det handlar mer om att befästa samhällskroppens kontinuitet och fortlevnad än att skilja ut den egna nationen som högre stående jämfört med andra nationer. Nationen representerar i de flesta nationalistiska ideologier en mytisk länk mellan ett folk och ett föreställt hemterritorium. För att verifiera denna länk mobiliserar nationalistiska ideologier en mängd identitetsmarkörer: myter om ett gemensamt ursprung, en gemensam historia som betonar nationella hjältar (som till exempel Engelbrekt, Gustav Vasa, men också myten om odalbonden eller den panegyriska gestaltningen av Per Albin Hansson), gemensamma minnen och glömskor (se vidare Hall 2000). Det kan också handla om att framhäva republikanska dygder, som medborgarskap och gemensamma normer. Nationalism uttrycker, som jag ser det, ett särskilt sätt att beskriva världen och ett särskilt sätt att prata på - en gemensam referensram och samtalsordning utifrån vilken "vi” organiserar verkligheten (se t.ex. Özkırımlı 20IO, s. 205 ff.).

Forskare inriktade på svensk nationalism brukar uppmärksamma en slags integrativ nationalism som betonar individens underordning under kollektivet. Henrik Berggren och Lars Trägårdh (2009) menar dock att såväl kollektivet (samhället och staten) som individen prioriteras i det svenska samhället på bekostnad av mellanmänskliga gemenskaper som familj och kyrka. Den svenska nationalismen har institutionaliserats och gjorts "normal". Det svenska territoriet är i den nationella historieskrivningen inte bara en politiskt neutral enhet, utan också ett moraliskt landskap där värderingar och principer om det rätta och det goda blivit institutionaliserade och därmed försanthållna (Hall 200o).

Det är i denna kontext som debatten om SD och deras politik förs. Den sverigedemokratiska utmaningen mot det politiska etablissemanget består inte så mycket $\mathrm{i}$ att den skulle vara nationalistisk, menar jag, utan snarare i att SD framhäver den svenska nationen på ett annorlunda sätt jämfört med vad de traditionella partierna (och de traditionella väljarna) vant sig vid. Den oro som infinner sig i samband med att SD gör entré i det offentliga rummet kan också följa av att "de goda demokraternas" 
nationalism synliggörs. SD:s framgångar ger associationer till, inte alltid så harmoniska, tongångar som spelats upp tidigare under historien för att konsolidera den demokratiska staten. Och kanske än mera störande är att SD:s närvaro på den politiska scenen ger uttryck för nationalistiska känslor som redan finns rotade hos majoritetsbefolkningen och kanaliserar dessa genom sin plats i riksdagen. Många vill vara stolta över vår kung och att internationella celebriteter besöker Sverige för att ta emot Nobelpriset utan att lägga smolk i glädjebägaren med alltför mycket hänsyn till allehanda oförrätter som begåtts i den svenska nationalismens namn eller vetskap om att kungen haft en del fuffens för sig i sitt privatliv. Det är fler än Jimmie Åkesson som anser att riksdagens öppnande är ett högtidligt, nationellt ögonblick.

SD underhåller och gör sig till företrädare för känslor och stämningar, som finns rotade i banala uttryck för nationalism i populärkultur och i litterära verk om att Sverige kanske är lite mer storslaget och lite mera förträffligt än andra nationer. Möjligen är det så att "de goda demokraterna" inte vill kännas vid SD för att partiet spelar på strängar i det nationella historiemedvetandet som i dag klingar falskt i mångas öron. De myter och minnen som SD vill plocka fram i den nationella historieskrivningen, för att åberopa nationell samling över klass- och generationsgränser, är inte uppenbart i takt med särskilt många svenskars föreställningar om det nya Sverige.

\section{Varför vi älskar att hata Sverigedemokraterna}

$\mathrm{SD}$ är kortet i kortleken som ingen vill ha på sin hand. Borgerliga kommentarer hänvisar till SD som ett välfärdschauvinistiskt projekt som attraherar missnöjda socialdemokrater, medan kommentatorer från den rödgröna sidan i stället kan tala om partiet som ett typiskt högerorienterat parti, som profiterar på en främlingsfientlig retorik och fackföreningsfientlig politik. Båda dessa röster kan i viss mån ha rätt. SD av årgång 2013 profilerar sig som ett socialkonservativt parti som både intar en värdekonservativ hållning i livsstilsfrågor och värnar om välfärdsstatens institutioner. SD:s kompromissvillighet i andra frågor än invandringspolitik och svenskhet öppnar för bedömare att placera partiet så nära motståndarsidan som möjligt. Vi kan alla hata SD. 
SD provocerar och väcker till liv politikens inneboende känslomässiga dragningskraft och moraliska underton, både i sin egen retorik och i sättet som "de goda krafterna” bemöter partiet på. I detta finns en smärta. Vi kan tvingas gräva i oss själva för att filtrera och formulera konkurrerande visioner om den nationella självbilden. I detta ryms också en särskild njutning. Genom att förena sig, från höger till vänster, mot en gemensam moralisk fiende kan samhörighet och tillhörighet till det nationella stärkas och bekräftas. Begreppet "jouissance" uttrycker just detta - att "vi" kan finna en särskild njutning-i-smärtan med avseende på SD:s frammarsch i den svenska offentligheten (Homer 20I0, s. 89). Det är centralt, påpekar Mouffe (2008, s. 33), att förstå hur kollektiva identitetsformationer, som ofta knyts till den egna nationen, formar och organiserar den representativa politiken - hur politikens passioner inverkar på det offentliga samtalet. Att gå och rösta, till exempel, handlar till syvende och sist om identifikation, att hitta en politisk typ som passar ens preferenser.

Den kollektiva identifikationen med ett "vi" möjliggörs och förstärks genom ett moraliskt avståndstagande mot "de andra", de som hotar vår njutning. Vi älskar att hata SD för att vi därigenom kan bekräfta vår godhet. Det politiska samtalet är inte bara en kamp mellan olika politiska viljeyttringar, utan inbegriper också en drivkraft att själv tillhöra den "goda sidan" (se vidare Hellström \& Nilsson 20ıо; Hellström 20IO). Att vi älskar att hata SD är ett uttryck för politikens "förlösande" sida, en strävan bland både företrädare och kritiker att kanalisera och infria löften hos väljarna om att en annan värld är möjlig.

Den offentliga debatten om SD och deras politik är polariserad och tillika moraliserad. Vi älskar att hata Sverigedemokraterna och detta hat kan få det som ses som de goda demokraternas nationalism att framstå som sund, naturlig och ofarlig just tack vare att den speglas mot SD:s nationalism som beskrivs som ond, bedräglig och farlig. Kampen om den nationella självbilden har möjligen accentuerats av SD:s närvaro i den nationella politiken, men diskussionen om vad som utgör samhällskroppens etos och gränser omförhandlas ständigt med eller utan SD i riksdagen. 


\section{Till sist}

Söndagen före valet 20 Io möttes statsministerkandidaterna Fredrik Reinfeldt och Mona Sahlin i en debatt i SVT. ${ }^{6}$ De ventilerade oenigheter rörande exempelvis försäkringssystemets utförande, avdrag för hushållsnära tjänster och skattelättnader. På en punkt var de påfallande överens. Reinfeldt förklarade att han absolut inte skulle samarbeta med, eller göra sig beroende av, ett parti som grundar sig på främlingsfientlighet. Sahlin applåderade sin motståndare och debatten avslutades i samförstånd. Det moraliska anslaget är tydligt riktat mot SD och bekräftade en åsiktskonvergens mellan blocken om invandringspolitiken. För presumtiva väljare som ansåg att en begränsning av invandringen till Sverige är en prioriterad fråga och att den svenska välfärdsstaten och svenska intressen bör skyddas mot personer och idéer som förknippas med mångkulturalism var en röst på SD antagligen inte långt borta.

Sverige har fătt ett nytt riksdagsparti. Vi kan möjligen anta att det kommer ske en ömsesidig anpassning mellan huvudfåran och "radikalhögern" som en följd av att det finns ytterligare ett parti att förhålla sig till i kampen om väljarnas röster. Frågan är om inte denna anpassning i så fall redan har skett. Under föregående mandatperiod föreslog Moderaterna ett särskilt startkontrakt, som i sin tur påminde om Socialdemokraternas "etableringskontrakt” från mandatperioden före. Folkpartiet lanserade språktest som villkor för medborgarskap i valrörelsen 2002 och har därefter initierat en diskussion om en särskild svensk litteraturkanon. I februari 2010 föreslog Kristdemokraterna en obligatorisk introduktionskurs för invandrare snarlik den undervisning som redan bedrivs av sfi. Flera bedömare ser instinktivt den här typen av förslag som en flirt med SD:s väljare. Men alla utspel som görs inom SD:s profilområden behöver inte nödvändigtvis tolkas som en eftergift till SD. Det vore att ge partiet tolkningsföreträde för vad "mannen på gatan" tycker om invandring och integration, vilket stämmer dåligt överens med de attitydundersökningar som visar att svenska folket, över tid, har blivit allt mindre främlingsfientliga och mer benägna att acceptera "mångkulturella" inslag i sin vardag (Demker 20I2).

6. Debatten, med titeln "Duellen", sändes I2 september 2010 i SVT och lades sedan upp på SVT Play (http://svtplay.se/v/2I4356I/valet_20Io/duellen, hämtat I5 september 20IO). 
Icke desto mindre finns det smittorisker. SD:s politik och världsbild som i sig utgår från och radikaliserar åsikter hos andra partier och strömningar - kan spilla över, vilket journalister nogsamt påpekar och politiker, inte minst efter valet 20Io, aktsamt försöker undvika eller skyla över. Men SD utmanar också bilden av oss själva, om svenskar som lite finare och mer toleranta än andra folk. Vi älskar att demonstrera vår avsky mot SD, som likt en syndabock får bära majoritetssamhällets samlade oförätter på sina axlar. SD kan i sin tur fortsätta spela rollen som demokratiska martyrer och stå som exponenter för det "sunda förnuftet". Åkesson står svarslös inför Gudrun Schyman i en debatt i SVT,7 och kan inte bemöta en BBC-reporters undran varifrån han hämtar sin statistik om invandrares högre brottsbenägenhet (Baas 20II). Inslag som dessa ger onekligen dem som hatar SD vatten på sin kvarn. Samtidigt finns det väljare som liksom Åkesson ondgör sig över Schymans omtalade "taliban-liknelse" (i debatten upprepade Åkesson ordet "taliban" i stället för att gå i sakpolitisk konfrontation med Schyman) och kan känna en viss förståelse för Åkessons begränsade förmåga att på engelska förklara "det som alla vet", nämligen att invandrare begår fler och värre brott än infödda svenskar, oavsett att statistik från exempelvis Brottsförebyggande rådet (BRÅ) antyder annorlunda.

Under en stormig höstvecka 2012 hamnar partiet åter på löpsedlarna (Hellström \& Kiiskinen [kommande]). Expressen har offentliggjort en film inspelad med mobiltelefon där två sverigedemokratiska företrädare, senare invalda i riksdagen, Erik Almqvist och Kent Ekeroth, tillsammans med en tredje partikamrat syns ute på stan efter en krogrunda i Stockholm sommaren 20I0. ${ }^{8}$ Filmen visar hur de beväpnar sig med järnrör efter en verbal konfrontation med den kände ståuppkomikern Soran Ismail. Den sistnämnde avfärdas som osvensk (trots att han har ett svenskt pass och själv ser sig som svensk) av Almqvist, som efter avslöjandet fick lämna riksdagen: "I mitt syfte så beter du dig som en babbe just nu. Och du har

7. I programmet "Agenda”. Debatten sändes 22 augusti 2010 och lades upp på SVT Play (http://svtplay.se/v/2II4036/debatt_mellan_schyman_och_akesson_i_agenda, hämtat Is september 20IO).

8. Filmen finns upplagd på Expressen TV som en del av programmet "Expressen Dokumentär: Hela SD-filmen" (http://www.expressen.se/tv/nyheter/inrikes/expressendokumentar-hela-sd-filmen, hämtat I8 december 20I2). 
inget här att göra ... det är mitt land”. En kvinna blandar sig i diskussionen och avfärdas med det nedsättande tillmälet "lilla horan".

Uppståndelsen över den publicerade filmen var mycket kraftig och flera opinionsbildare uttryckte sin avsky över agerandet. Många ansåg att partiet nu hade visat sitt sanna ansikte (Orrenius 20I2). Samtidigt fortsätter partiet att öka i opinionsmätningarna även efter skandalen. Sverige är delat mellan en majoritet som älskar att hata SD och en till synes växande minoritet som sympatiserar med partiet. Diskussionen om partiets nyligen inrättade nolltolerans mot rasism och de uteslutningar som följt har aktualiserat och ytterligare spätt på dessa spänningar. Båda sidor har fått vatten på sin kvarn efter den senaste skandalen. SD är ett parti som både lider av och profiterar på sitt utanförskap.

Det är skönt att hata SD, men det hjälper föga för att utmana de föreställningar som ligger till grund inte bara för SD:s väljare, utan också för många andra som räds slitningar i samhället. Faran med SD är kanske inte deras eventuella extremism, utan att "det normala" förskjuts i en extrem riktning samtidigt som samtalsklimatet förblir polariserat mellan dem som älskar att hata SD och dess anhängare.

Inför klimatmötet i Köpenhamn 2009 varnade Danmarks vice statsminister Lene Espersen för att det största hotet mot vår existens och våra gemensamma värderingar stavas islam, inte klimatförändringarna (Stilling 2009). Runtom i Europa har extrema partier som profiterar på ett främlingsfientligt budskap vunnit terräng, inte minst i länder som blivit särskilt hårt ansatta av den ekonomiska krisen, exempelvis Grekland. Även i flera andra länder har det skett en ökad konvergens mellan "radikalhögern" och huvudfåran i europeisk politik. Det här är en händelseutveckling som vi kan bekräfta "vår goda svenskhet" gentemot. Ska vi därmed sluta oss till att "andra folk" är mer rasistiska och intoleranta än vad "vi är"? Det vore att bekräfta föreställningar om svenskar som mer toleranta och gästvänliga än andra. För att förstå SD:s roll och position i svensk politik och historia behöver vi rota lite i oss själva, vilket kan göra ont. Demonstrationerna som arrangerades dagarna före riksdagens öppnande, biskopens tal i storkyrkan och SD:s uttåg är tecken i tiden på en självbild i gungning. Vi behöver för den skull inte trilla av gungan baklänges. 


\section{Referenser}

Abbott, Philip 2007. "Bryan, Bryan, Bryan, Bryan": Democratic Theory, Populism, and Philip Roth's "American Trilogy". Canadian Review of American Studies 37, 3, s. $43 \mathrm{I}-452$. DoI: http://dx.doi.org/I0.3138/cras.37.3.43I

Appadurai, Arjun 2007. Vredens Geografi. Rädslan för de fätaliga. Stockholm: Tankekraft. Awayez, Natik 2006. Myten om paradiset före invandrarna. Sydsvenskan, I2 oktober 2006.

Baas, David 20II. Här pressas Jimmie Åkesson i BBC. Expressen, 25 januari 2011. URL: http://www.expressen.se/nyheter/har-pressas-jimmie-akesson-i-bbc (I februari 2OII)

Berggren, Henrik \& Trägårdh, Lars 2009. Är svensken människa? Gemenskap och oberoende $i$ det moderna Sverige. Stockholm: Norstedts.

Betz, Hans-Georg \& Johnson, Carol 2004. Against the Current - Stemming the Tide: The Nostalgic Ideology of the Contemporary Radical Populist Right. Journal of Political Ideologies 9, 3, s. 31I-327.

DOI: http://dx.doi.org/Io.Io8o/I356931042000263546

Billig, Michael 1995. Banal Nationalism. London: Sage.

Blehr, Barbro 2000. En norsk besvärjelse. I7 maj-firande vid Igoo-talets slut. Nora: Nya Doxa.

Brunne, Eva 20Io. Biskop Eva Brunnes predikan - ord för ord. Expressen, 5 oktober 20 o.

Canovan, Margaret 1999. Trust the People! Populism and the Two Faces of Democracy. Political Studies 47, I, s. 2-16.

DoI: http://dx.doi.org/Io.IIII/I467-9248.00I84

Canovan, Margaret 2004. Populism for Political Theorists? Journal of Political Ideologies 9, 3, s. 24I-252.

DOI: http://dx.doi.org/I0.I080/1356931042000263500

Demker, Marie 20I2. Positiv attityd till invandring trots mobilisering av invandringsmotstånd, i Weibull, Lennart, Oscarsson, Henrik \& Bergström, Annika (red.) I framtidens skugga. Fyrtiotvå kapitel om politik, medier och sambälle. SOM-undersökningen 20II. Göteborg: SOM-institutet.

Ekelund, Fredrik 2006. Etniska svenskar föraktas. Sydsvenskan, 4 oktober 2006.

Ekman, Mikael \& Poohl, Daniel 20IO. Ut ur skuggan. En kritisk granskning av Sverigedemokraterna. Stockholm: Natur \& Kultur.

Forsberg, Johannes 2006. På besök hos mörkerkrafterna. Expressen, I2 december 2006.

Freeden, Michael 1998. Is Nationalism a Distinct Ideology? Political Studies 46, 4, s. $748-765$.

DoI: http://dx.doi.org/I0.IIII/I467-9248.00165

Hall, Patrik 200o. Den svenskaste historien. Nationalism i Sverige under sex sekler. Stockholm: Carlsson.

Hellström, Anders 20Io. Vi är de goda. Den offentliga debatten om Sverigedemokraterna och deras politik. Hägersten: Tankekraft. 
Hellström, Anders \& Kiiskinen, Jenny [kommande]. Populismens dubbla ansikte, i Petersson, Bo \& Johansson, Christina (red.) IMER idag. Aktuella perspektiv på Internationell migration och etniska relationer. Stockholm: Liber.

Hellström, Anders \& Nilsson, Tom 20Io. "We Are the Good Guys". Ideological Positioning of the Nationalist Party Sverigedemokraterna in Contemporary Swedish Politics. Ethnicities IO, I, s. 55-76.

DoI: http://dx.doi.org/IO.II77/I4687968093542I4

Henriksson, Dick 2oIo. SD:s uttåg ur kyrkan väckte irritation. Göteborgs-Posten, 6 oktober 2010 .

Holmberg, Sören 2007. Sverigedemokrater: vilka är dom och vad vill dom?, i Holmberg, Sören \& Weibull, Lennart (red.) Det nya Sverige. Göteborg: SOM-institutet.

Homer, Sean 20IO. Jacques Lacan. London: Routledge.

Hägglund, Göran 2009. Sveriges radikala elit har blivit den nya överheten. Dagens Nyheter, 17 september 2009 .

Jomshof, Richard 2008. "Att jag ändå fick gå berodde på att skolan var rädd för skriverier", i Leandersson, Jens (red.) 20 röster om 20 är. Sverigedemokraterna 1988-2008. Helsingborg: Blåsippans förlag.

Kiiskinen, Jenny \& Saveljeff, Sigrid 2oro. Att dansa i otakt med väljarna. Socialdemokraternas och Moderaternas strategiska bemötande av Sverigedemokraterna. Malmö: IMER.

Laclau, Ernesto 2005. On Populist Reason. London: Verso.

Larsson, Stieg \& Ekman, Mikael 20or. Sverigedemokraterna. Den nationella rörelsen. Stockholm: Ordfront.

Lewander, Jakob 20Io. Ohly vägrar sminkas med Åkesson. Nyheter24, I9 september 20 Iо. URL: http://nyheter24.se/nyheter/462579-lars-ohly-vagrar-sminkas-tillsammansmed-jimmie-akesson (i9 september 20I0).

Melin, Lena 20Io. Omoget, Åkesson. Aftonbladet, 6 oktober 2010.

Meret, Susi 2009. The Danish People's Party, the Italian Northern League and the Austrian Freedom Party in a Comparative Perspective. Party Ideology and Electoral Support. Ålborg: Institut for Historie, Internationale Studier og Samfundsforhold.

Mouffe, Chantal 2008. Om det politiska. Hägersten: Tankekraft.

Mudde, Cas 2007. Populist Radical Right Parties in Europe. Cambridge: Cambridge University Press.

Orrenius, Niklas 20ı. Jag är inte rabiat, jag äter pizza. En bok om Sverigedemokraterna. Stockholm: Månpocket.

Orrenius, Niklas 20I2. Skandalen kommer att fortsätta förfölja SD. Expressen, 25 november 2012.

Osignerad ledare 20Io. Parti nära ett sammanbrott. Aftonbladet, 24 maj 2010.

Peterson, Thage G. 2007. Våga ta debatten med Sd. Sydsvenskan, 25 februari 2007.

Ravik Jupskås, Anders 20Io. Sverigedemokraterna bör ses som ett vanligt parti. Sydsvenskan, 20 november 2010.

Rydgren, Jens 20Io. Den radikala högerns sociologi, i Deland, Mats, Hertzberg, Fredrik \& Hvitfeldt, Thomas (red.) Det vita fältet. Samtida forskning om högerextremism. Uppsala: Historiska institutionen, Uppsala universitet. 
Sannerstedt, Anders 2008. De okända väljarna: en analys av de skånska väljarna som röstade på icke riksdagspartier 2006, i Nilsson, Lennart \& Antoni, Rudolf (red.) Medborgarna, regionen och flernivådemokratin. Göteborg: SOM-institutet.

Skalin, Johnny 20Io. SD är inget högerparti, SvD!, från Skalins blogg, 16 mars 2010. URL: http://www.sdkuriren.se/blog/index.php/skalin/2010/03/16/sd_ar_inget_ hogerparti_svd (I juni 20IO)

Stavrakakis, Yannis 2004. Antinomies of Formalism: Laclau's Theory of Populism and the Lessons from Religious Populism in Greece. Journal of Political Ideologies 9, 3, s. $253-267$. DOI: http://dx.doi.org/Io.1080/1356931042000263519

Stenberg, Ewa 20ı. Hård kritik mot SD:s uttåg. Dagens Nyheter, 6 oktober 2010.

Stilling, Simon 2009. Lene: Militante muslimer truer de danske værdier. Ekstra Bladet, I6 augusti 2009.

Ström, Sofia 20Io. Nobelfest - utan Åkesson. Svenska Dagbladet, 28 oktober 20 Io.

Svensson, Alf 2007. Människor kan inte värderas i pengar: Alf Svensson (kd) om mörkermän och människosyn. Göteborgs-Tidningen, 25 april 2007.

Sverigedemokraterna 2010a. Politiska riktlinjer, från Sverigedemokraternas hemsida. URL: http://sverigedemokraterna.se/valet-20IO (I juni 20IO)

Sverigedemokraterna 2oıob. En återupprättad välfärd. Sverigedemokraternas skuggbudget våren 20I0, från Sverigedemokraternas hemsida.

URL: http://sverigedemokraterna.se/valet-20IO (I juni 20IO)

Taggart, Paul 2002. Populism and the Pathology of Representative Politics, i Mény, Yves \& Surel, Yves (red.) Democracies and the Populist Challenge. Basingstoke: Palgrave.

Taguieff, Pierre-André 1990. The New Cultural Racism in France. Telos, nr 83, s. I09-I22. DoI: http://dx.doi.org/I0.3817/0390083109

Tamas, Gellert 2002. Lasermannen. En berättelse om Sverige. Stockholm: Ordfront.

TT Spektra 2007. Nobeldagen blir reklamfri i TV4. Svenska Dagbladet, 7 december 2007.

Weigl, Kerstin 20Io. De beter sig som småbarn. Aftonbladet, 6 oktober 2010.

Wennerhag, Magnus 2008. Global rörelse. Den globala rättviserörelsen och modernitetens omvandlingar. Stockholm: Atlas.

Wodak, Ruth 2002. Friend or Foe. The Defamation or Legitimate and Necessary Criticism? Reflections on Recent Political Discourse in Austria. Language \& Communication 22, 4, s. 495-517.

DOI: http://dx.doi.org/Io.IoI6/So27I-5309(02)00022-8

Žižek, Slavoj 200o. Varför älskar vi att hata Haider? Om extremhögern, politiska sockerpiller och små blåa och röda påsar. Ord \& Bild, $\mathrm{nr}$.

Åkesson, Jimmie 2007. Jimmie Åkessons tal inför Riksårsmötet 2007, från bloggen Olofströms sverigedemokrater, 22 maj 2007.

URL: http://steen.bloggspace.se/II7733/Jimmie-Akessons-tal-infor-

Riksarsmotet-2007 (I juni 20IO) 
Åkesson, Jimmie 20IO. Tal på valkonferensen, från bloggen Åkesson om, 29 mars 2010 (talet hölls 27 mars). URL: http://www.sdkuriren.se/blog/index.php/akesson/20Io/o3/29/tal_pa_ valkonferensen (I juni 20I0)

Özkırımlı, Umut 20IO. Theories of Nationalism. A Critical Introduction. 2 uppl. Basingstoke: Palgrave Macmillan. 
Hur blir man medborgare och vad betyder det att vara medborgare? Medborgarskapet kan vara den efterlängtade slutdestinationen för en lång och mödosam flykt, men det kan också vara startpunkten för en svårdefinierbar integrationsprocess. Antologin VÄGAR TILL MEDBORGARSKAP handlar om

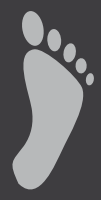

medborgarskapets villkor och förutsättningar i Sverige och världen idag.

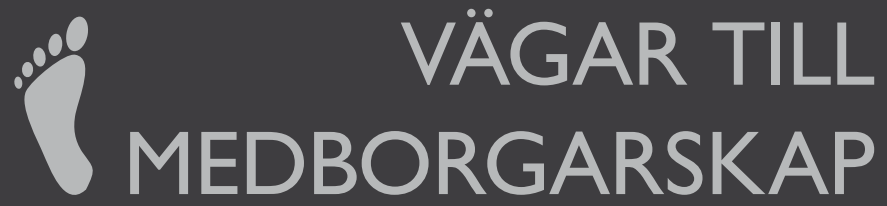

Pieter Bevelander, i Christian Fernández \& Anders Hellström (red)

Arkiv förlag 20II, danskt band, I73 sidor »Läs mer om boken på www.arkiv.nu巛 